\title{
Dopamine-Modulated Potassium Channels on Rat Striatal Neurons: Specific Activation and Cellular Expression
}

\author{
Gabriela J. Greif, Yong-Jian Lin, June-Chih Liu, and Jonathan E. Freedman \\ Department of Pharmaceutical Sciences, Northeastern University, Boston, Massachusetts 02115
}

We have used cell-attached patch-clamp electrophysiology to characterize the activation and distribution of an $85 \mathrm{pS}$ $\mathrm{K}^{+}$channel on freshly dissociated rat striatal (caudate-putamen) neurons. In recordings from 643 cells, openings of this channel showed an absolute dependence on the presence of dopamine or the $D_{2}$-like dopamine receptor agonist quinpirole in the cell-attached patch pipette, but were never seen when the $D_{2}$ antagonist domperidone was applied along with quinpirole, or in the absence of drug. This channel displayed inward rectification at depolarized membrane potentials, but its activation was otherwise voltage insensitive. It was largely restricted to a subset of dissociated cells with diameters $\geq 10 \mu \mathrm{m}$, with channel openings seen in about $25 \%$ of patches. When present, there were typically multiple channels per patch. Cells of this size were immunocytochemically stained for neuron-specific enolase but not glial fibrillary acidic protein; about $40 \%$ were also labeled for $\gamma$-amino butyric acid (GABA) and about $60 \%$ for NADPH diaphorase, with GABAergic cells displaying a shape most similar to that of cells expressing the channel. A large number of distinct types of other channels were also present, comprising inwardly rectifying channels of 5$35 \mathrm{pS}$ conductance and voltage-activated channels of 100$250 \mathrm{pS}$, but the frequencies of occurrence and fractional open times of these channels were independent of the presence or absence of dopaminergic agonists. Thus, the $85 \mathrm{pS} \mathrm{K}$ channel uniquely requires activation by a $D_{2}$-like dopamine receptor on rat striatal neurons, and is selectively expressed by a subset of these cells, which are most likely to be GABAergic neurons.

[Key words: dopamine, quinpirole, patch clamp, $K^{+}$channel, inward rectification, caudate-putamen, striatum, NADPH diaphorase]

Much interest has centered on the actions of dopamine in the CNS and its probable roles in various neurological and psychiatric diseases (Bunney et al., 1991; Seeman and Van Tol, 1994). Several dopamine receptor subtypes have been identified and cloned; these can be placed into " $\mathrm{D}_{1}$-like" and " $\mathrm{D}_{2}$-like" groups

\footnotetext{
Received Dec. 9, 1994; revised Feb. 6, 1995; accepted Feb. 7. 1995.

We thank Xiaogang Zhang for help with the immunocylochemistry, and Dr. Forrest $F$. Weight, in whose laboratory at NIAAA preliminary experiments leading to this project were begun. This work was supported by NIH FIRST Award MH-48595 and by grants from the Pharmaceutical Manufacturers $\Lambda \mathrm{s}$ sociation Foundation and the Tourette Syndrome Association.

Correspondence should be addressed to Jonathan E. Freedman, Ph.D., 211 Mugar Building. Northeastern University, 360 Huntington Avenue, Boston, MA 02115 .

Copyright (O) 1995 Society for Neuroscience $0270-6474 / 95 / 154533-12 \$ 05.00 / 0$
}

(Gingrich and Caron, 1993). To understand dopaminergic function, it is important to know how dopamine receptors regulate neuronal excitability through modulation of membrane ion channels. $\mathrm{D}_{2}$-like dopamine receptors are known to activate $\mathrm{K}^{\prime}$ channels in pituitary cells (Einhorn et al., 1991). $\mathrm{D}_{2}$-like receptors are also known to mediate membrane hyperpolarization by activating a $\mathrm{K}^{+}$conductance in dopamine-containing neurons in the substantia nigra (Lacey et al., 1987); this leads to inhibition of cell firing (Bunney et al., 1973). Other studies performed in central neurons have implicated other ionic conductances in dopaminergic action as well (L.-X. Liu et al., 1992, 1994; Surmeier et al., 1992, 1993a).

Patch-clamp electrophysiology can identify ion channels with single-molecule resolution, making it a potentially useful tool to approach the question of dopamine receptor signal transduction. We are therefore using single-channel recording to identify and characterize dopamine-modulated ion channels on freshly dissociated neurons of the rat corpus striatum (caudate-putamen), a major postsynaptic target of brain dopaminergic projections. The dissociated cell preparation offers the additional capability of attributing pharmacologic effects directly to the cell being recorded, rather than to indirect trans-synaptic effects. In earlier

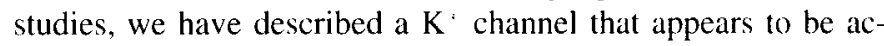
tivated by $\mathrm{D}_{2}$-like dopamine receptors on these cells (Freedman and Weight, 1988). This channel has a conductance of $85 \mathrm{pS}$ and utilizes $\mathrm{K}^{+}$as the principal charge carrier (Freedman and Weight, 1988). Subsequent studies showed that this channel is blocked by low nanomolar concentrations of quinine (Freedman and Weight, 1989; Cass and Zahniser, 1990), and can also be modulated by the metabolic state of the cell (Lin et al., 1993).

The pharmacologic characterization of this channel as being activated by $\mathrm{D}_{2}$-like dopamine receptors was essentially a preliminary study on a limited number of cells (Freedman and Weight, 1988). Here, we have sought to take into account the heterogeneity of the striatal cell population, as well as to assess whether there might be other dopamine receptor-modulated K channels on these cells. We have consequently extended these earlier studies to a much larger number of neurons. Additionally, we have used some cytochemical techniques to characterize the types of cells present after dissociation among this heterogeneous cell population, and to determine which cells might express this channel response. In performing these studies, we have observed the presence of other $\mathrm{K}^{+}$-permeable channels as well. We report that sensitivity to dopamine receptor agonists appears to be specific to the $85 \mathrm{pS}$ channel, which has an absolute dependence on $\mathrm{D}_{2}$-like dopamine receptor agonists for its activation, and that this channel is differentially distributed among striatal cells, with selective expression by a neuronal sub- 
type sharing at least some properties with medium spiny neurons.

\section{Materials and Methods}

Cell preparation. Caudate-putamen neurons were freshly dissociated from 30-45-d-old male Sprague-Dawley rats (CD-COBS or VAF lines, Charles River Laboratories, Wilmington. MA) by modifications of previously described methods (Freedman and Weight, 1988). The brain was rapidly and gently removed into the following ice cold medium (in mM): sucrose, $235 ; \mathrm{KCl}, 2 ; \mathrm{CaCl}_{2}, 1 ; \mathrm{MgCl}_{2}, 1 ; \mathrm{MnCl}_{2}, 0.02 ;$ D-glucose, 25; piperazine- $N, N^{\prime}$-bis-(2-ethanesulfonic acid) (PIPES)-Na, 20, pH 7.0; osmolality, 330-340 mOsm $/ \mathrm{kg}$; equilibrated with $100 \% \mathrm{O}_{2}$ ("PIPESsucrose"). The composition of this medium was based in part on the observations of Kay and Wong (1986) that a pH 7.0 PIPES buffer was favorable for brain cell dissociation, and of Aghajanian and Rasmussen (1989) that replacing $\mathrm{NaCl}$ with sucrose promoted viability of brain slices. Coronal sections $(200 \mu \mathrm{m})$ of caudate-putamen were prepared near $0^{\circ} \mathrm{C}$ with a vibrating tissue slicer, while blocking the tissue so as to exclude nucleus accumbens, globus pallidus, and other adjacent regions. The slices were transferred to an incubation chamber containing $12 \mathrm{ml}$ of PIPES-sucrose under $100 \% \mathrm{O}_{2}$, stirred continuously at $25 \mathrm{rpm}$, and gradually warmed to $32^{\circ} \mathrm{C}$. Trypsin (type XI, Sigma Chemical Co., St. Louis, MO; 26,000 benzoyl arginine ethyl ester units) was then added, and the tissue incubated for $1 \mathrm{hr}$. Soybean trypsin inhibitor $(0.25$ $\mathrm{mg} / \mathrm{ml}$ ) was then added for $5 \mathrm{~min}$. The slices were then washed with three changes of Dulbecco's modified Eagle's medium (DMEM), without bicarbonate, and with $25 \mathrm{~mm} N$-(2-hydroxyethyl)piperazine- $N^{\prime}-(2$ ethanesulfonic acid) (HEPES), pH 7.4, adjusted with $\mathrm{NaCl}$ to 330-340 $\mathrm{mOsm} / \mathrm{kg}$, and incubation was continued for up to $6 \mathrm{hr}$. As needed, two slices were taken up in about $0.5 \mathrm{ml}$ of DMEM and dissociated by trituration, with two passes through a plastic pipette tip (type RC-200, Rainin Instrument Co., Woburn, MA). The cells were plated on polyornithine-coated polystyrene petri dishes, allowed to settle for $10 \mathrm{~min}$, and used for either patch-clamping or cytochemistry within about $1 \mathrm{hr}$. Cells were viewed with at Nikon Diaphot microscope, typically under phase-contrast optics. We restricted our experiments to cells that appeared phase-bright and retained some neuritic processes. The number of viable cells obtained by this modified procedure was generally greater than in earlier studies (Freedman and Weight, 1988). Approximate cell diameters were estimated as the sonatic dianter along the major axis, excluding processes, using a calibrated eyepiece reticle.

Immunocvtochemistry. The cells were fixed with $4 \%$ paraformaldehyde in phosphate-buffered saline (PBS) for 10 min at room temperature. They were then washed with $\mathrm{NH}_{4} \mathrm{Cl}(0.5 \mathrm{mg} / \mathrm{ml})$ in PBS, followed by four changes of PBS. The cells were permeabilized with $0.01 \%$ Triton $\mathrm{X}-100$ in PBS for 1 min, then washed four times with PBS containing $10 \%$ normal goat serum and $1 \mathrm{mg} / \mathrm{ml} \mathrm{NaN}_{3}$ (PBS-NGS). The cells were then incubated with the primary antibody in PBS-NGS for I hr at $30^{\circ} \mathrm{C}$. Primary antibodies were a rabbit polyclonal antibody to neuron-specific enolase (NSE) (Polysciences Inc., Warrington, PA; 1:4000), a mouse monoclonal antibody to glial fibrillary acidic protein (GFAP) (Chemicon International, Temecula, CA; 1:400), and a rabbit polyclonal antibody to $\gamma$-amino butyric acid (GABA) (Sigma; $1: 2000$ ). In each experiment. control dishes were simultaneously incubated without primary antibody. The cells were then washed four times with PBSNGS, then treated with Cy3-conjugated goat secondary antibodies to rabbit or mouse immunoglobin $G$ (Chemicon, 1:200 in PBS-NGS) for $1 \mathrm{hr}$ at $30^{\circ} \mathrm{C}$. The cells were then washed five times with PBS and viewed with a rhodamine fluorescence filter set and mercury lamp illumination. Before viewing fluorescence, the cells were viewed under phase-contrast optics, and cells that appeared fragmented or damaged were rejected; all other cells present were included in the analysis.

NADPH diaphorase cytochemistry. NADPH diaphorase was stained by a modification of the method of Vincent and Kimura (1992). Cells were fixed as for immunocytochemistry, incubated with nitro blue te trazolium $(0.1 \mathrm{mg} / \mathrm{ml})$, NADPH $(1.0 \mathrm{mg} / \mathrm{ml})$, and Triton X-100 $(0.3 \%)$ in PBS for $30 \mathrm{~min}$ at $30^{\circ} \mathrm{C}$, then washed three times with PBS. In double-labeling experiments, diaphorase staining was performed after incubation with the secondary antibody.

Patch-clamp electrophsiology. The cells were continuously superfused with (in mM) $\mathrm{NaCl}, 149 ; \mathrm{KCl}, 3.5 ; \mathrm{CaCl}_{2}, 2.5 ; \mathrm{MgCl}_{2}, 1$; 1 -glucose. 10; HEPES-Na, 10, pH 7.4; adjusted with sucrose to 330-340 $\mathrm{mOsm} / \mathrm{kg}$ and equilibrated with $100 \% \mathrm{O}_{2}$. Electrodes were pulled from borosilicate glass (type 7740$)$ capillaries $(1.5 \mathrm{~mm}$ o.d., $0.84 \mathrm{~mm}$ i.d., with filament; World Precision Instruments, Sarasota. FL), coated with
Sylgard, and heat polished to a tip diameter of about $1 \mu \mathrm{m}$. and had resistances of about $2 \mathrm{M} \Omega$ when filled with solution. Patch pipettes contained (in mM) KCl, $140 ; \mathrm{CaCl}_{2}, 2.5 ; \mathrm{MgCl}_{2}, 1$; HEPES-K, $10, \mathrm{pH}$ 7.4. plus drugs as indicated. Domperidone was from Sigma, and quinpirole and dopamine were from Research Biochemicals (Natick. MA). Dopamine solutions also contained $100 \mu \mathrm{M}$ ascorbic acid.

Patch-clamp recordings were performed in the cell-attached configuration. We continue to observe cellular deterioration during whole-cell recordings from these cells, as previously reported (Freedman and Weight, 1988), and consequently have focused on simgle-clanmel measurements in this study. Before attempting to record from any cell, its approximate diameter and cell shape were noted. Criteria for satisfactory recordings were seal resistance greater than $5 \mathrm{GS}$ channel current reversal potentials greater than $50 \mathrm{mV}$ depolarized from resting membrane potential (when currents were present), and stable phase-bright cell appearance for the duration of the recording, which normally was at least $10 \mathrm{~min}$. Since these cells rarely survived withdrawal of the patch pipette, we only tested one patch per cell. Inder our experimental conditions, it was usually possible to obtain satisfactory recordings from about 10 cells per day.

Currents were measured with an Axopatch-1D patch-clamp system and analyzed with pCl.AMP software (Axon Instruments. Foster City. CA). After filtering at $2 \mathrm{kHz}$ low-pass, currents were acquired at 100 $\mu$ sec/point to a 386-based desktop computer and were viewed on line with an analog oscilloscope to verify accurate digital acquisition. During each experiment, we varied the pipette potential to estimate the amplitude of the single-channel conductance, to assess whether channel activation was voltage-sensitive, and to identify the reversal potential and the zero-current level. During selected experiments. we collected data to disk at various voltages and determined single-channel conductance as the slope of current-voltage plots; the linear portion of the plot, typically negative to the reversal potential, was fitted by linear regression in cases where rectification was present. Membrane potential in these cell-attached recordings has been expressed relative to resting potential (as the pipette potential multiplied by -1 ); whole cell recordings from these celis previously indicated resting potentials around $-55 \mathrm{mV}$ (Freedman and Weight, 1988). $\mathrm{K}^{+}$channel currents were measured as inward currents, with reversal potentials expected near $0 \mathrm{mV}$ membrane potential (with $140 \mathrm{~mm} \mathrm{~K}$ in the patch pipette). In all experiments. channel current reversal potentials were determined, and were consistently at $50-60 \mathrm{mV}$ depolarized from resting potential, as would be expected for a current carried principally by $\mathrm{K}^{+}$under these recording conditions.

Inward currents have been graphed as positive. The number of active channels in the patch was estimated from simultaneous openings detected throughout the ohservation period of approximately $10 \mathrm{~min}$. Digital records of at least 25,600 points were routinely used to generate all-points amplitude histograms. We verified that these records were long enough to encompass bursting periods and give representative re sults, by performing selected longer acquisitions and by repeating and comparing acquisitions during the experiment. Fractional open and closed times were determined from the areas under the peaks of amplitude histograms; only patches containing a single type of channel were used for these determinations. The open probability $P_{\text {, w }}$ was defined as $1-N P_{\text {ch }}$ where $N$ was the number of channels in the patch, and the closed probability $P$, was the fraction of time no channel current was passed. Statistical comparisons of cell populations were performed by a $x^{2}$ test.

\section{Results}

When viewed under phase-contrast optics, freshly dissociated striatal cells displayed a variety of sizes and shapes (Fig. I). Short neuritic processes were present, but structures such as dendritic spines were generally not preserved. The lengths of the retained processes varied from cell to cell in each preparation, and we restricted our recordings to phase-bright cells retaining some processes, to reduce the likelihood of recording from damaged or unidentifiable cells. Approximate cell diameters ranged between 5 and $30 \mu \mathrm{m}$. [Although interneurons of larger size are known to be present in striatum in situ (Kawaguchi, 1993), we believe that they generally do not survive the dissociation procedure. We have only seen one cell of this size (about $50 \mu \mathrm{m}$ ) 

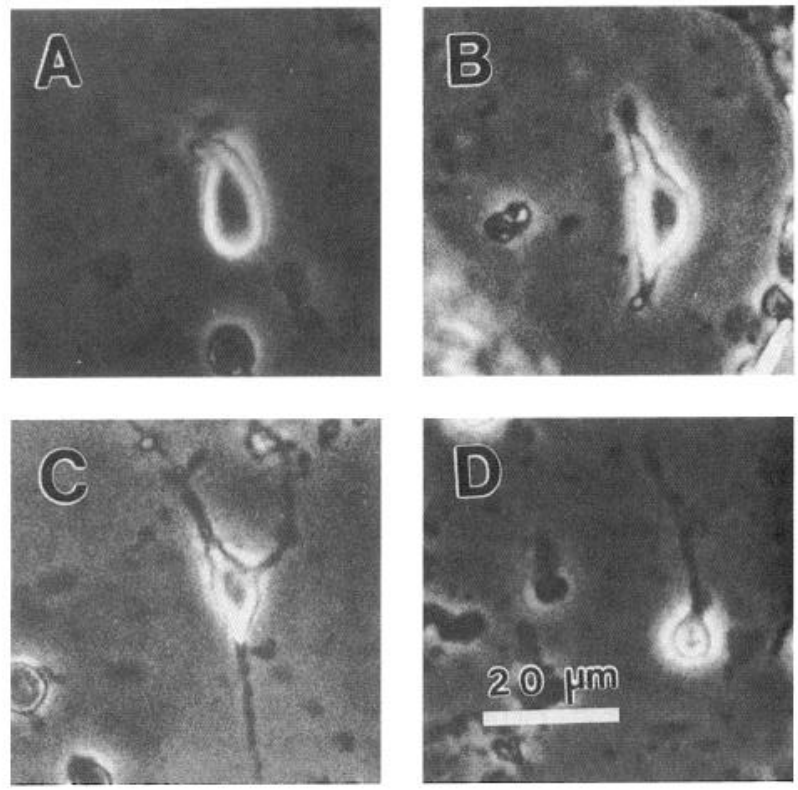

Figure 1. Phase-contrast photomicrographs of freshly dissociated rat striatal neurons. $A-C$, Examples of "large" cells, showing variation in cell shapes. The cells in $A$ and $C$ were selected to show two extremes of shapes. D, A "small" cell. Definitions of "large" and "small" cells are given in Results. Scale bar applies to $A-D$.

in our preparation, and were not able to detect any ion channels in a single patch from this cell.] For routine phase-contrast observation during electrophysiologic recording, we operationally subdivided the dissociated cells into "large" cells, defined as having diameters $\geq 10 \mu \mathrm{m}$ and typically multiple processes, and "small" cells, with diameters $<10 \mu \mathrm{m}$ and a single process. "Large" cells displayed a variety of morphologies, ranging from quasi-pyramidal and somewhat rounded cell bodies (Fig. 1A) to more angular and multipolar in shape (Fig. $1 C$ ), with intermediate shapes present as well (Fig. $1 B$ ). "Small" cells consistently had only one process and a spherical or slightly ovoid cell body (Fig. 1D).

Cytochemical experiments revealed further heterogeneities within each of these two cell groups. We performed immunochemical labeling of neuron-specific enolase (NSE), glial fibrillary acidic protein (GFAP), and $\gamma$-amino butyric acid (GABA), as well as cytochemical staining of NADPH diaphorase (Fig. 2). In each case, we verified the specificity of immunocytochemical labeling by omission of the primary antibody. Only one cell was fluorescent (and lightly so) in the absence of primary antibody (Tables 1, 2), suggesting that nonspecific labeling occurred in fewer than $1 \%$ of cells. Labeling was distributed throughout the cytoplasm, and was absent from nuclei. The neuronal marker NSE labeled all of the "large" cells observed, and about $70 \%$ of the "small" cells (Table 1). The glial marker GFAP, in contrast, labeled about $30 \%$ of the "small" cells and none of the "large" cells (Table 1). Thus, about $30 \%$ of "small" cells were glia, while $70 \%$ of "small" cells and most "large" cells were neurons.

Immunostaining for GABA was observed in about $40-50 \%$ of "large" cells and about 50-60\% of "small" cells (Table 2). NADPH diaphorase labeling was observed in about $60 \%$ of both "large" and "small" cells (Table 2). To assess whether these were distinct cell populations, we performed some double labeling of both GABA and NADPH diaphorase. There were some
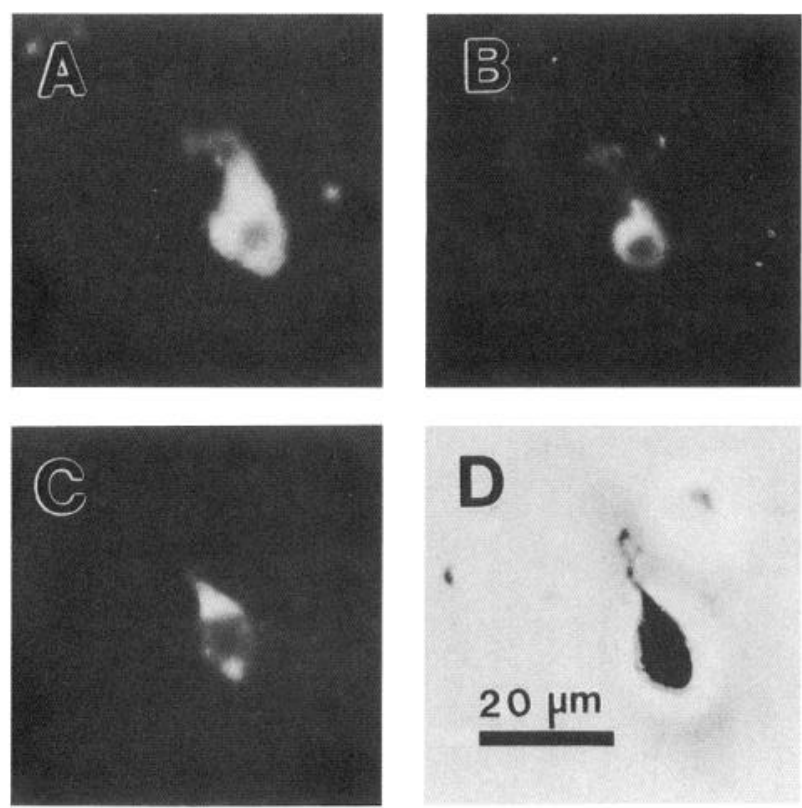

Figure 2. Cytochemical labeling of freshly dissociated rat striatal neurons. $A-C$ are fluorescence photomicrographs of immunocytochemical labeling. $A$, A "large" cell, labeled for neuron-specific enolase. $B, A$ "small" cell, labeled for neuron-specific enolase. $C$, A "large" cell, labeled for GABA. The more diffuse labeling in $C$ was characteristic of GABA labeling in "large" cells; GABA labeling in "small" cells as well as labeling for other markers was typically more intense. $D, \mathrm{~A}$ "large" cell, cytochemically stained for NADPH diaphorase, and viewed under bright-field optics. Definitions of "large" and "small" cells are given in Results. Scale bar applies to $A-D$.

clear examples of both "large" and "small" cells labeled for both GABA and diaphorase, although there were larger numbers of cells expressing one marker only. Labeling for a single marker was especially noticeable among "large" cells, where there was a trend for cells with shapes like that of the cell in Figure $1 A$ to be labeled only for diaphorase $(90 \%)$, and for cells with shapes like the cell in Figure $1 C$ to be labeled only for GABA (72\%), with cells of intermediate shapes giving variable results (Table 2). Similarly, in single-labeling experiments, $90 \%$ of the cells that were immunoreactive for GABA were of angular/multipolar or intermediate shape, whereas $88 \%$ of the cells stained for diaphorase were of quasi-pyramidal or intermediate shape. Given the variety of intermediate cell shapes and the presence of double labeling, however, this classification can not be ab-

Table 1. Immunocytochemical labeling of dissociated striatal cells

\begin{tabular}{llcc} 
Antigen & Cell type & $\begin{array}{l}\text { Cells } \\
\text { observed }\end{array}$ & $\begin{array}{l}\text { Cells } \\
\text { labeled }(\%)\end{array}$ \\
\hline NSE & "Large" & 28 & $28(100 \%)$ \\
& "Small" & 126 & $86(68 \%)$ \\
Control $^{2}$ & "Large" & 5 & $0(0 \%)$ \\
& "Small" & 29 & $0(0 \%)$ \\
GFAP & "Large" & 19 & $0(0 \%)$ \\
& "Small" & 147 & $41(27 \%)$ \\
Control" & "Large" & 12 & $0(0 \%)$ \\
& "Small" & 46 & $0(0 \%)$
\end{tabular}

The primary antibody was omitted from the incubation in control experiments performed in parallel. 
Table 2. Cytochemical labeling of GABA and NADPH diaphorase

\begin{tabular}{|c|c|c|c|c|c|c|}
\hline Label & Cell type & $\begin{array}{l}\text { Cells } \\
\text { observed }\end{array}$ & $\begin{array}{l}\text { Cells } \\
\text { labeled } \\
(\%)\end{array}$ & & & \\
\hline \multirow[t]{5}{*}{ GABA } & "Large" & 46 & $19(41 \%)$ & & & \\
\hline & Quasi-pyramidal/rounded & & $2(10 \%$ of 19$)$ & & & \\
\hline & Intermediate & & $7(37 \%$ of 19$)$ & & & \\
\hline & Angular/multipolar & & $10(53 \%$ of 19$)$ & & & \\
\hline & "Small" & 342 & $219(64 \%)$ & & & \\
\hline \multirow[t]{2}{*}{ Control ${ }^{a}$} & "Large" & 18 & $0(0 \%)$ & & & \\
\hline & "Small" & 91 & $1(1 \%)$ & & & \\
\hline \multirow[t]{5}{*}{ Diaphorase } & "Large" & 66 & $40(61 \%)$ & & & \\
\hline & Quasi-pyramidal/rounded & & $17(43 \%$ of 40$)$ & & & \\
\hline & Intermediate & & $18(45 \%$ of 40$)$ & & & \\
\hline & Angular/multipolar & & $5(12 \%$ of 40$)$ & & & \\
\hline & "Small" & 434 & $268(62 \%)$ & & & \\
\hline \multirow{7}{*}{$\begin{array}{l}\text { Double } \\
\text { labeling }\end{array}$} & & & Cells labeled & & & \\
\hline & Cell type & $\begin{array}{l}\text { Cells } \\
\text { observed }\end{array}$ & $\begin{array}{l}\text { GABA }+ \\
\text { diaphorase }\end{array}$ & $\begin{array}{l}\text { GABA } \\
\text { only }\end{array}$ & $\begin{array}{l}\text { Diaphorase } \\
\text { only }\end{array}$ & $\begin{array}{l}\text { No } \\
\text { label }\end{array}$ \\
\hline & "Large" & 70 & $12(17 \%)$ & $22(31 \%)$ & $36(52 \%)$ & $0(0 \%)$ \\
\hline & Quasi-pyramidal/rounded & 20 & $1(5 \%)$ & $1(5 \%)$ & $18(90 \%)$ & $0(0 \%)$ \\
\hline & Intermediate & 36 & $9(25 \%)$ & $11(31 \%)$ & $16(44 \%)$ & $0(0 \%)$ \\
\hline & Angular/multipolar & 14 & $2(14 \%)$ & $10(72 \%)$ & $2(14 \%)$ & $0(0 \%)$ \\
\hline & "Small" & 185 & $46(25 \%)$ & $48(26 \%)$ & $63(34 \%)$ & $28(15 \%)$ \\
\hline
\end{tabular}

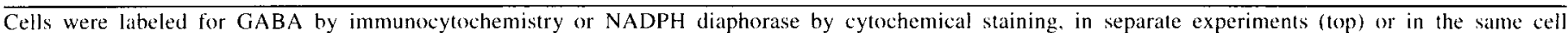

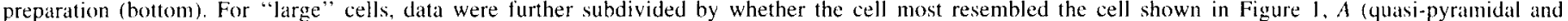

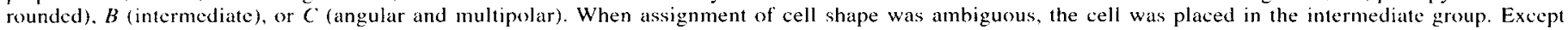
where indicated, percentage values are expressed as percentage of cells observed.

"The primary antibody was omitted from the incubation in control experiments performed in parallel.

solute. All "large" cells examined appeared to be labeled for at least one of these markers. In preliminary experiments, retrograde labeling with fluorescent latex microspheres injected into the substantia nigra was seen in some of the "large" cells, with shapes like those labeled for GABA, but was not seen in "small" cells (B. L. Waszczak, unpublished observations).

In cell-attached patch-clamp recordings from "large" cells, some patches expressed the $85 \mathrm{pS} \mathrm{K}^{+}$channel when $10 \mu \mathrm{M}$ dopamine or quinpirole (a $\mathrm{D}_{2}$-like dopamine receptor agonist, Hahn and MacDonald, 1984; Stoof and Kebabian, 1984) were present within the patch pipette (Fig. $3 A$ ). As previously reported (Freedman and Weight, 1988), these channel currents had linear current-voltage relationships with a conductance near $85 \mathrm{pS}$ (84.7 $\pm 5.5 \mathrm{pS}$, mean $\pm \mathrm{SD}, n=30$ patches) at membrane potentials negative to the reversal potential. The conductance values obtained in individual experiments fitted a normal distribution with a single mode (Kolmogorov-Smirnov normality test), and the only evidence we observed of possible heterogeneity of channels with conductances in this range was a slight variability in fractional open time (see below). In all experiments, channel current reversal potentials were consistent with $\mathrm{K}^{+}$being the principal charge carricr, as expected from previously reported measurements of reversal potential change as a function of $\mathrm{K}^{+}$concentration (Freedman and Weight, 1988). Channel openings typically occurred in bursts, and were apparent as soon as the seal was formed. Fractional open time was independent of membrane potential at voltages negative to the reversal potential, with some patch-to-patch variability in nuInerical value, but typically $>0.5$ (Fig. $3 B$ ). Outward currents could not be detected at voltages positive to the reversal poten- tial (Fig. 3B). Thus, this channel displayed inward rectification, but its gating was otherwise voltage insensitive. Recordings were stable for up to $-30 \mathrm{~min}$, and showed no evidence of desensitization.

We studied the relationship between the presence or absence of dopamine receptor agonists and the occurrence of channel openings on a total of 643 "large" and "small" cells (Tables 3 . 4). On "Iarge" cells, channel activation showed an absolute dependence on the presence of dopaminergic agonists, since $85 \mathrm{pS}$ channel openings were never observed in 130 recordings in the absence of drugs (Table 3). However, with either dopamine or quinpirole present in the patch pipette, $85 \mathrm{pS}$ channel openings were seen in about $25 \%$ of patches tested (Table 3 ). When the selective $\mathrm{D}_{2}$-like dopamine receptor antagonist domperidone (500 nм; Laduron and Leysen, 1979; Stoof and Kebabian, 1984) was combined with quinpirole, channel openings were not seen (Table 3). We tested a sufficient number of cells that the effects of agonists as well as of domperidone were clearly statistically significant (Table 3). In other studies, 7-OH-DPAT, a $\mathrm{D}_{2}$-like agonist with partial $D_{3}$ selectivity, was effective at eliciting openings of the channel (J.-C. Liu et al., 1994), and the $\mathrm{D}_{2}$ antagonist spiperone as well as the less $D_{2}$-selective antagonist haloperidol appeared to suppress channel openings (Freedman and Weight, 1988). In contrast to "large" cells, "small" cells never displayed the $85 \mathrm{pS}$ channel, either in the presence or in the absence of agonists, and again this was statistically significant (Table 4). [Since many "small" cells expressed channels of other conductances, with reversal potentials consistent with resting membrane potentials negative to $-50 \mathrm{mV}$ (see below), we feel that it is unlikely that "small" cells failed to express the 
A.

Control

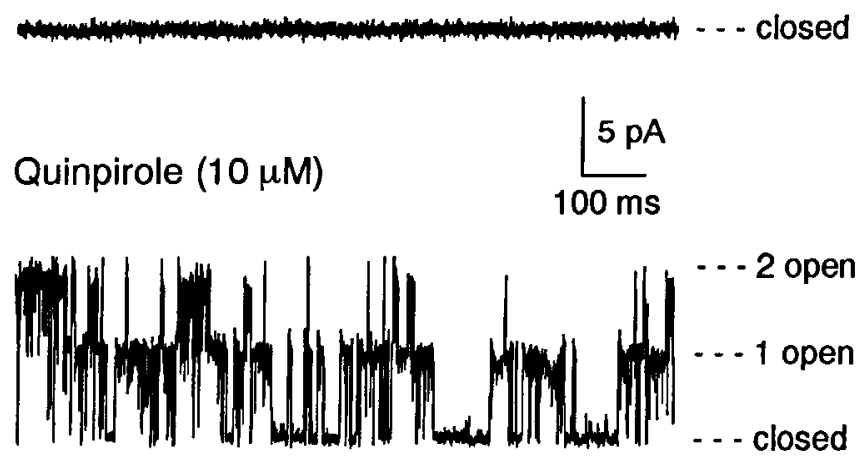

Quinpirole $(10 \mu \mathrm{M})+$ Domperidone $(500 \mathrm{nM})$
B.

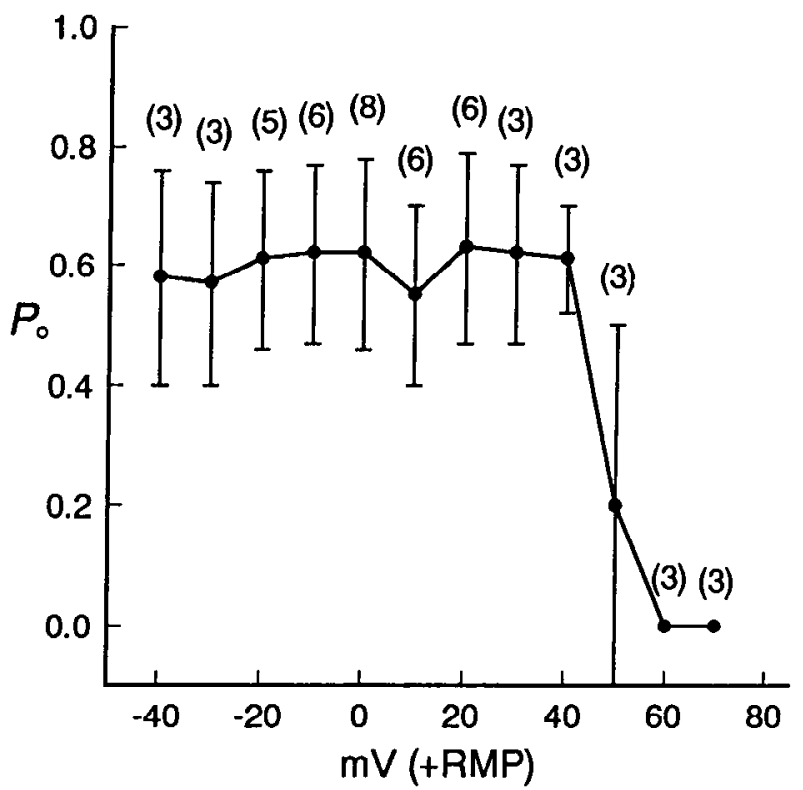

Figure 3. Properties of $85 \mathrm{pS} \mathrm{K} \mathrm{K}^{+}$channels. A, Examples of single-channel recordings. The cell-attached patch pipette contained no drug (top) trace), $10 \mu \mathrm{M}$ quinpirole (center trace), or $10 \mu \mathrm{M}$ quinpirole plus $500 \mathrm{nM}$ domperidone (bottom trace); records are from three different patches from "large" cells. The records are at resting membrane potential. Upward deflections correspond to inward currents. $B$, Fractional channel open probability $\left(P_{0}\right)$ of the $85 \mathrm{pS} \mathrm{K}{ }^{+}$channel as a function of membrane potential. Data are expressed as mean \pm SD. The number of cells used for measurements at each point is given in parentheses. The mean values are connected by lines on the graph; no mathematical relationship is implied. The large variation at $50 \mathrm{mV}$ depolarized reflects the presence of channel currents in some patches and their absence in others, as membrane potential approached the reversal potential. $R M P$, resting membrane potential.

$85 \mathrm{pS}$ channel due to damage during tissue dissociation.] As with GABA immunolabeling, there was a trend for patches from cells shaped like the cell in Figure $1 C$ to be the most likely to express the channel, although it may have been present less frequently on other "large" cells as well (Table 5). When openings of the $85 \mathrm{pS}$ channel were observed, it was unusual to encounter only a single channel molecule of this conductance per patch (nominally about $1 \mu \mathrm{m}$ diameter of patch membrane). Instead, there were typically two to four channels present in most patches where they were observed (Fig. 4).

In some experiments, more than one kind of channel current could be detected in the same patch (Fig. $5 A$ ). In addition to the $85 \mathrm{pS} \mathrm{K}^{+}$channel, we observed various channels of both larger and smaller conductance (Fig. 5A). In every case, they had reversal potentials at about $50-60 \mathrm{mV}$ depolarized from resting membrane potential, consistent with $\mathrm{K}^{+}$permeability under our recording conditions. Smaller-conductance channel currents typically were interrupted by fewer brief closures than were those of the $85 \mathrm{pS}$ channel (Fig. $5 B$ ). Current-voltage plots revealed a variety of conductances, over a continuous range between about $5 \mathrm{pS}$ (which was near the lower limit of resolution in our recordings) and about $35 \mathrm{pS}$ (Fig. $5 C$ ). There were sufficiently many single-channel conductances within this range that it is not possible to state definitively how many distinct channel types there were. Conductances between 35 and $75 \mathrm{pS}$ were never observed. When carrying inward $\mathrm{K}^{+}$currents at voltages negative to the reversal potential, open probability was about 0.5 0.6 and was voltage-insensitive (Fig. 5D). Outward currents were not detected at voltages positive to the reversal potential (Fig. $5 D$ ), indicating that these channels were inwardly rectify-

Table 3. Occurrence of $85 \mathrm{pS} \mathrm{K}^{+}$channel openings on "large" cells

\begin{tabular}{|c|c|c|c|}
\hline Pipette solution & Palches tested & Patc & $\begin{array}{l}\text { hes with channel } \\
(\%)\end{array}$ \\
\hline No drug & 117 & 0 & $(0 \%)$ \\
\hline Ascorbic acid $(100 \mu \mathrm{M})$ & 13 & 0 & $(0 \%)$ \\
\hline Total control & 130 & 0 & $(0 \%)$ \\
\hline Dopamine $(10 \mu \mathrm{M})+$ ascorbic acid $(100 \mu \mathrm{M})$ & 211 & 50 & $(24 \%)$ \\
\hline Quinpirole $(10 \mu \mathrm{M})$ & 141 & 39 & $(27 \%)$ \\
\hline Total agonists & 352 & $89^{*}$ & $(25 \%)$ \\
\hline Quinpirole $(10 \mu \mathrm{M})+$ domperidone $(500 \mathrm{nM})$ & 25 & \multicolumn{2}{|c|}{$0 * *(0 \%)$} \\
\hline
\end{tabular}

*P<0.001 vs "total control."

$* * P<0.01$ vs "total agonists." 
Table 4. Occurrence of $85 \mathrm{pS} \mathrm{K}$ channel openings on "small" cells

\begin{tabular}{lcc} 
& $\begin{array}{c}\text { Patches } \\
\text { with } \\
\text { channel } \\
(\%)\end{array}$ \\
\hline Pipette solution & 35 & $0(0 \%)$ \\
Po drug & 8 & $0(0 \%)$ \\
Ascorbic acid $(100 \mu \mathrm{M})$ & 43 & $0(0 \%)$ \\
$\quad$ Total control & 56 & $0(0 \%)$ \\
Dopamine $(10 \mu \mathrm{M})+$ ascorbic acid $(100 \mu \mathrm{M})$ & 62 & $0(0 \%)$ \\
Quinpirole $(10 \mu \mathrm{M})$ & 118 & $0 *(0 \%)$ \\
$\quad$ Total agonists & \begin{tabular}{l} 
test \\
\hline
\end{tabular}
\end{tabular}

"P<0.001 vs the corresponding value for "large" cells in Table 3 .

ing. Thus, these channels resembled the $85 \mathrm{pS}$ channel in their inward rectification, but could be clearly distinguished from it by their smaller conductances.

We characterized the frequency of observation of these channels as a function of the presence or absence of dopamine receptor agonists in the patch pipette. On "large" cells, channels of this conductance range were seen in approximately $24 \%$ of patches tested, whether or not dopamine or quinpirole were present (Table 6). Similarly, on "small" cells about $19 \%$ of patches expressed these channels, regardless of the presence or absence of agonists (Table 6). Thus, in contrast to the situation with the $85 \mathrm{pS}$ channel, these results fail to support a role for dopaminergic modulation of the small-conductance channels.

It is, however, possible that dopamine could modulate channel properties, even if channel openings occurred in its absence. Therefore, we further examined whether channel open probability (fractional open time, as opposed to the occurrence of channel openings) of small-conductance channels was influenced by the presence of agonists. On both "large" and "small" cells, there was no difference in open probability between patches treated with agonists and patches treated with control solution, nor was there any discernible evidence that only a subset of these channels was affected, based on examination of data grouped into narrower conductance ranges (Table 7).

In some patches, we observed channels with much larger conductances (Figs. 5A, 6A). These channels occurred less frequently in our recordings. They typically had conductances that were clearly larger than the $85 \mathrm{pS}$ channel, and invariably differed from other channels in that they were activated by membrane depolarization, even though some openings were present at negative potentials (Fig. 6A). Again, these channels consistently had reversal potentials consistent with $\mathrm{K}^{+}$permeation under our recording conditions. A number of different conductances were seen, ranging between about $100 \mathrm{pS}$ and about $250 \mathrm{pS}$ (Fig. 6B). Channel current amplitude varied ohmically with voltage (Fig. $6 B$ ). Open probability was relatively low at hyperpolarized membrane potentials, and increased markedly with membrane depolarization (Fig. 6C,D). These larger channels were also observed in either the presence or the absence of dopamine receptor agonists in the patch pipette. They were observed in only about $3 \%$ of patches from "large" and $2 \%$ of "small" cells, whether or not dopamine or quinpirole was present (Table 8).

To assess whether the open probability of these channels was influenced by agonists, it was also necessary to account for the effect of membrane potential on open probability. Since recordings were obtained in the cell-attached configuration, where rest-
Table 5. Morphologies of "large" cells expressing 85 pS K channels

\begin{tabular}{llc} 
Cell shape & $\begin{array}{l}\text { Cells } \\
\text { observed }\end{array}$ & $\begin{array}{l}\text { Cells with } \\
\text { channel }(\%)\end{array}$ \\
\hline Quasi-pyramidal/rounded & 108 & $3(3 \%)$ \\
Intermediate & 167 & $45(27 \%)$ \\
Angular/multipolar & 77 & $41(53 \%)$
\end{tabular}

The cells reported on the "total agonists" line of Table 3 were calegorized by cellular shape as described in Table 2 notes.

ing membrane potential can not be measured directly, small differences in resting potential from cell to cell might complicate comparisons of voltage between one cell and another. We there fore separately plotted open probability as a function of voltage for recordings in the absence (Fig. $6 C$ ) and the presence (Fig. $6 D$ ) of agonists, to compare the slopes of the plots as a function of voltage, as well as the absolute value of open probability at each voltage. Both these measures were similar between patches treated with agonists and patches treated with control solution, although at negative membrane potentials open probability was very slightly higher in patches treated with agonists (Fig. 6C,D).

Taken together, these results suggest that neither the smallconductance inwardly rectifying channels nor the large-conductance voltage-activated channels were sensitive to dopamine. This is summarized in Figure 7. In the absence of dopamine receptor agonists, the range of single-channel conductances that we observed fell into two groups, corresponding to these two channel types (Fig. 7A). This pattern was not appreciably different when agonists were present in the pipette. but a tight cluster of conductances around $85 \mathrm{pS}$, which was absent in control recordings, was now conspicuously apparent (Fig. 7B). The pattern of channel occurrence at $<35 \mathrm{pS}$ was essentially indistinguishable between agonists and control. At higher conductances (specifically, 100-125 and 150-175 pS), there were slight differences between the two data sets, but in light of the small

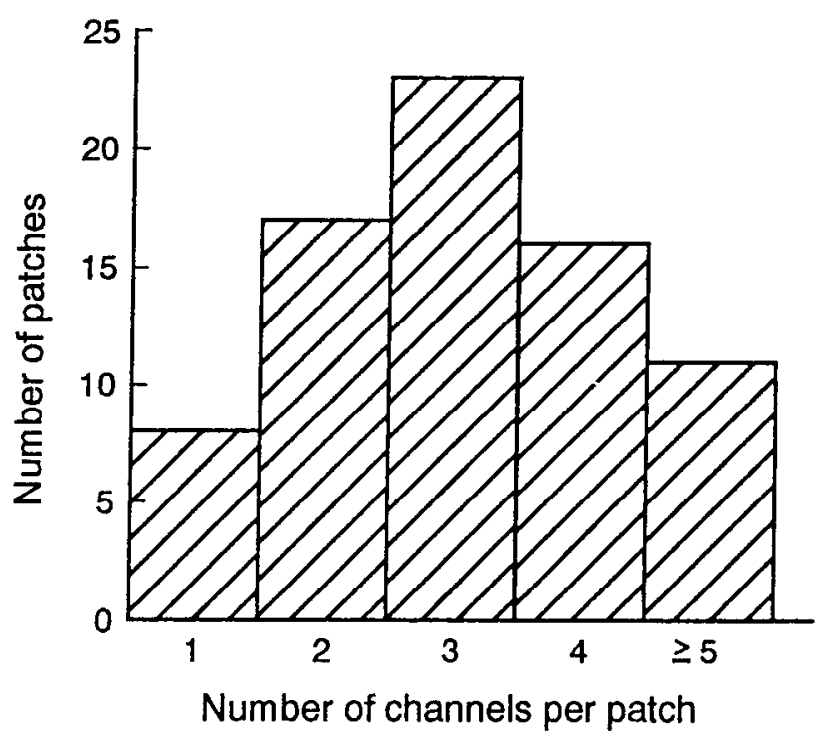

Figure 4. Distribution of numbers of $85 \mathrm{pS} \mathrm{K}$ channels per patch tested. The number of channels in the patch is given on the $x$-axis. The number of patches found to express the indicated number of channels is given on the $y$-axis. Patches with zero channels are excluded from the figure. 

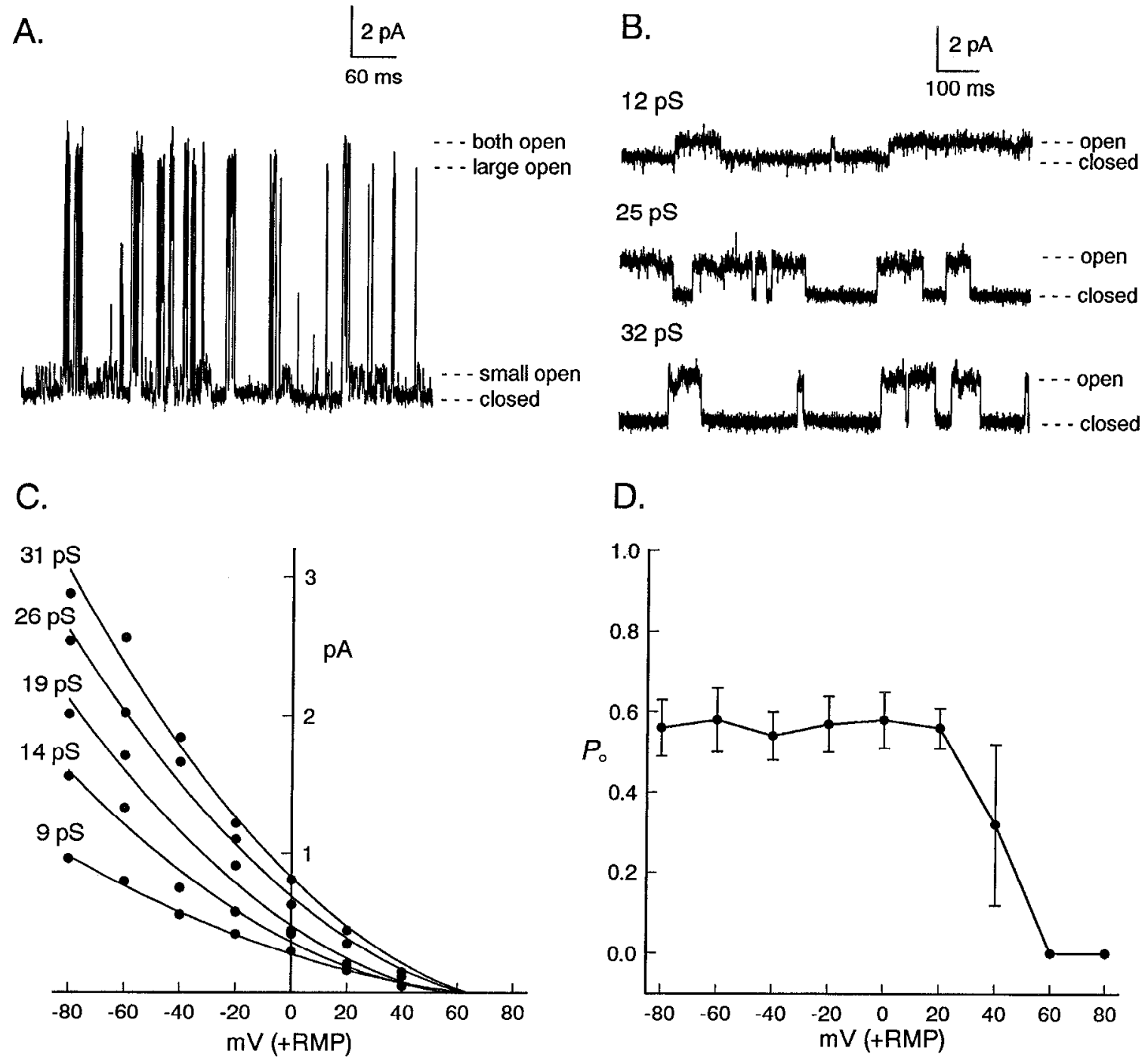

Figure 5. Examples of other channels. A, Example of a recording where a large-conductance channel (160 pS) and a small-conductance channel (12 pS) were present simultaneously. The recording was at $20 \mathrm{mV}$ hyperpolarized relative to resting membrane potential. Upward deflections correspond to inward currents. $B-D$, Properties of small-conductance channels. $B$, Recordings of small-conductance channels. Three different channels recorded in different experiments are shown, labeled by their conductances. All recordings were at $40 \mathrm{mV}$ hyperpolarized relative to resting membrane potential, and are shown at the same scale. $C$, Current-voltage relationships for small-conductance channels. Values for five different experiments are plotted. Conductances were obtained at resting membrane potential and more negative voltages. The curves were fit by second-order polynomial regression. $R M P$, resting membrane potential. $D$, Fractional channel open probability $\left(P_{o}\right)$ as a function of membrane potential, for small-conductance channels. Data are expressed as mean $\pm \mathrm{SD}$, for $n=5$ experiments. The mean values are connected by lines on the graph; no mathematical relationship is implied.

numbers of channels observed, there is no reason to attribute these small differences to the presence of dopaminergic agonists.

\section{Discussion}

The major findings of this study are that the $85 \mathrm{pS} \mathrm{K}^{+}$channel of rat striatal neurons has an absolute dependence on dopamine receptor agonists for its activation, unlike numerous other channels expressed by these neurons, and that it is selectively expressed by a subset of striatal cells. To account for potential variability in results due to the heterogeneity of the striatal cell population, we have sampled an especially large number of dissociated cells. We have modified our original method of cell preparation (Freedman and Weight, 1988), resulting in a greater diversity of size and shape among the cells obtained, and we have sought to relate cell morphology to electrophysiologic response.
It has been pointed out that it is important to assess in any in vitro system whether cell properties differ from in vivo (Bloch and LeMoine, 1994; Gerfen and Keefe, 1994). The half-life of dopamine receptor turnover as assessed after covalent modification (Hamblin and Creese, 1983) or antisense oligonucleotide suppression. (Weiss et al., 1993) appears longer than the time course of our cell preparation procedure and electrophysiological experiments, and so we feel that our in vitro system can probably be used validly, as long as responses are compared to dopamine effects in vivo when known. However, our cytochemical experiments clearly reveal one difference from the intact striatum, and results obtained from dissociated cells should be considered carefully in this regard. Whereas only about $2 \%$ of rat striatal neurons express NADPH diaphorase in situ (Dawson et al., 1991), we see labeling of about $60 \%$ of dissociated cells. Thus, the cell preparation procedure either selects for survival 
Table 6. Occurrence of small-conductance channel openings in the presence and absence of dopaminergic agonists

$\begin{array}{llc} & \begin{array}{l}\text { Patches } \\ \text { with } \\ \text { channel } \\ (\%)\end{array} \\ \text { Pipette solution } & \begin{array}{l}\text { Patches } \\ \text { tested }\end{array} & \begin{array}{l}\text { (\%) } \\ \text { "Large" cells }\end{array} \\ \text { Control } & 130 & 28(22 \%) \\ \text { Dopamine }(10 \mu \mathrm{M})+\text { ascorbic acid }(100 \mu \mathrm{M}) & 211 & 54(26 \%) \\ \text { Quinpirole }(10 \mu \mathrm{M}) & 141 & 32(23 \%) \\ \quad \text { Total agonists" } & 352 & 86(24 \%) \\ \text { "Small" cells } & 43 & 8(19 \%) \\ \text { Control } & 62 & 12(19 \%) \\ \text { Dopamine }(10 \mu \mathrm{M})+\text { ascorbic acid }(100 \mu \mathrm{M}) & 56 & 10(17 \%) \\ \text { Quinpirole }(10 \mu \mathrm{M}) & 118 & 22(19 \%) \\ \quad \text { Total agonists" } & \end{array}$

"The sum of the data for dopamine and for quinpirole.

of cells expressing the enzyme, or induces the enzyme, or both. NADPH diaphorase labeling is generally associated with the enzyme nitric oxide synthase (Dawson et al., 1991), which is known to exist in several forms, some of which are inducible (Nathan, 1992), and so it is plausible that the cell preparation procedure might have induced this enzyme. However, since we consistently see debris from damaged cells in our preparation, it seems equally likely that diaphorase neurons may survive differentially. Such cells are known to survive differentially in Huntington's disease (Ferrante et al., 1985).

Nonetheless, the labeling of our dissociated cells seems to correlate well with some of the types of cells known to be present in situ. The cells that we operationally described as "small" cells are a heterogeneous population of both neuronal and glial cells (as indicated by NSE and GFAP immunolabeling), whereas the "large" cells are largely or entirely neurons. About $60 \%$ of all our dissociated cells seem likely to be various NADPH diaphorase-containing interneurons, some of which are known to have sizes and shapes similar to some of our "large" cells (Kawaguchi, 1993), and some of which are likely to be the interneurons containing both GABA and nitric oxide synthase ( $\mathrm{Ku}$ bota et al., 1993). Other interneuron types may be present as well, especially among the "small" cells. None of the "small" cells appeared to express the dopamine-modulated $\mathrm{K}^{+}$channel. Although it is possible that some large diaphorase interneurons expressed this channel, this probably did not occur very often
(Table 5). It is probable that many of the remainder of "large" cells are GABAergic medium spiny projection neurons. We base this conclusion on (1) the presence of GABA immunoreactivity, (2) appropriateness of cell size, (3) preliminary evidence from retrograde labeling that some of these cells are projection neurons, and (4) the fact that such cells are the major cell type in intact striatum (Kita and Kitai, 1988; Reiner and Anderson, 1990). Based on correlation of cell shape with clcctrophysiology and cytochemistry, we believe that these are the cells most likely to express the dopamine-modulated $\mathrm{K}^{+}$channel in our experiments.

Our studies with dopamine and quinpirole confirm previous evidence (Freedman and Weight, 1988) that this $\mathrm{K}^{+}$channel is activated by $\mathrm{D}_{2}$-like dopamine receptors, and extend those findings by demonstrating that the channel open probability is essentially zero in the absence of receptor activation, implying that the channels require receptor activation to open. There is probably a homogeneous population of $85 \mathrm{pS} \mathrm{K}$ channels on these cells. Although these channels displayed some variability in fractional open times, we speculate that this might reflect cellto-cell variation in metabolic state (Lin et al., 1993), as well as varying degrees of receptor occupancy, each of which might affect channel activation. We chose to use a rather high concentration $(10 \mu \mathrm{M})$ of dopamine or quinpirole to be sure of detecting any channel molecules present in the membrane patch being tested; further studies will be needed to determine the concentration dependence of channel activation. At the concentration we employed (500 nM), the dopaminergic antagonist domperidone is expected to block essentially all $\mathrm{D}_{2}$-like receptors while having little or no effect on $D_{1}$-like receptors (Laduron and Leysen, 1979; Stoof and Kebabian, 1984). The absence of channel openings in the presence of domperidone is consistent with a $\mathrm{D}_{2}$-like pharmacology, but the specific $\mathrm{D}_{2}$-like receptor subtype(s) involved is not yet known.

We rarely observed patches with only a single $85 \mathrm{pS} \mathrm{K}$ chan nel, instead seeing either no channels or multiple channels per patch. This suggests that the channels, as well as the receptors. may exist in closely packed clusters on the membrane. It is possible that we saw the channel in roughly half the patches collected from putative medium spiny cells, if the channels were in fact restricted to GABAergic neurons (Table 5). This might suggest that most GABAergic "large" cells express this channel in scattered clusters, and some membrane patches from which we recorded included these clusters of channels while others did not, thus underestimating the true number of cells expressing the

Table 7. Open probabilities of small-conductance channels in the presence and absence of dopaminergic agonists

\begin{tabular}{llll} 
& & $P_{n}[$ mean \pm SD $(n)]$ & \\
\cline { 3 - 4 } & Conductance range & Control $^{\prime \prime}$ & Agonist" \\
\hline "Large" cells & $<10 \mathrm{pS}$ & $0.53 \pm 0.05(n=5)$ & $0.18 \pm 0.10(n-5)$ \\
& $10-20 \mathrm{pS}$ & $0.60 \pm 0.10(n=4)$ & $0.57 \pm 0.15(n=4)$ \\
& $20-35 \mathrm{pS}$ & $0.66 \pm 0.09(n=5)$ & $0.67 \pm 0.09(n=4)$ \\
"Small" cells & $<10 \mathrm{pS}$ & $0.45 \pm 0.11(n=3)$ & $0.48 \pm 0.09(n=3)$ \\
& $10-20 \mathrm{pS}$ & $0.49 \pm 0.17(n=3)$ & $0.51 \pm 0.05(n=3)$ \\
& $20-35 \mathrm{pS}$ & $0.52 \pm 0.09(n=3)$ & $0.58 \pm 0.13(n=4)$
\end{tabular}

$P$, was determined at resting membrane potential.

"No drug in patch pipette solution.

"Dopamine or quinpirole in patch pipette solution. 
A.

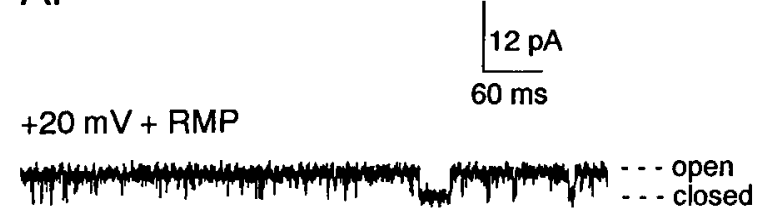

RMP

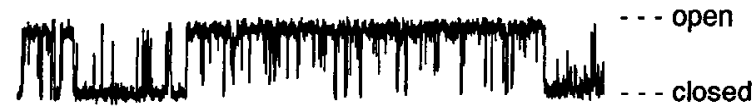

$-20 m V+R M P$

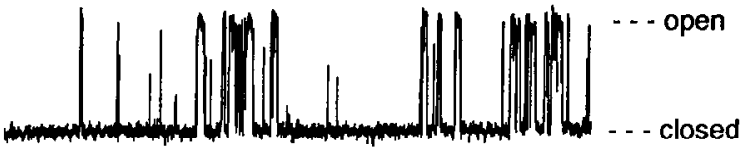

C.

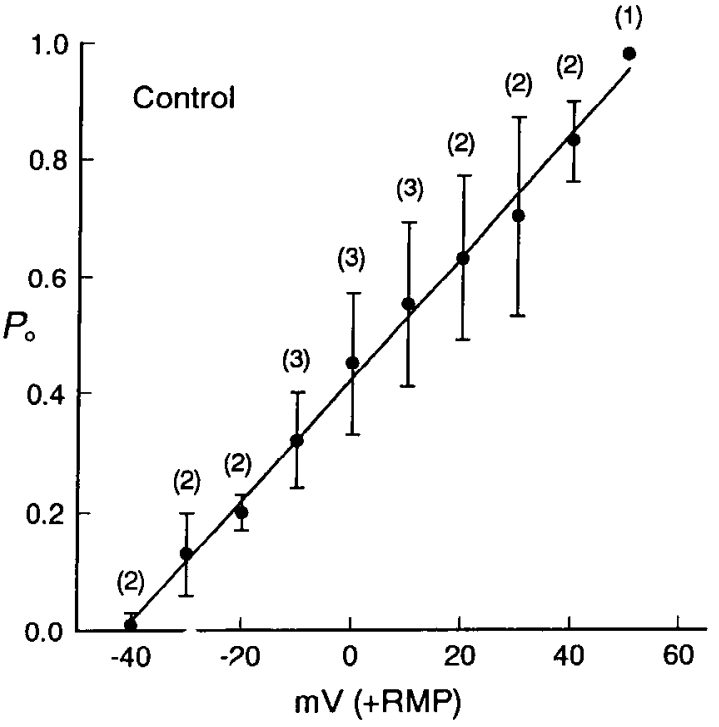

B.

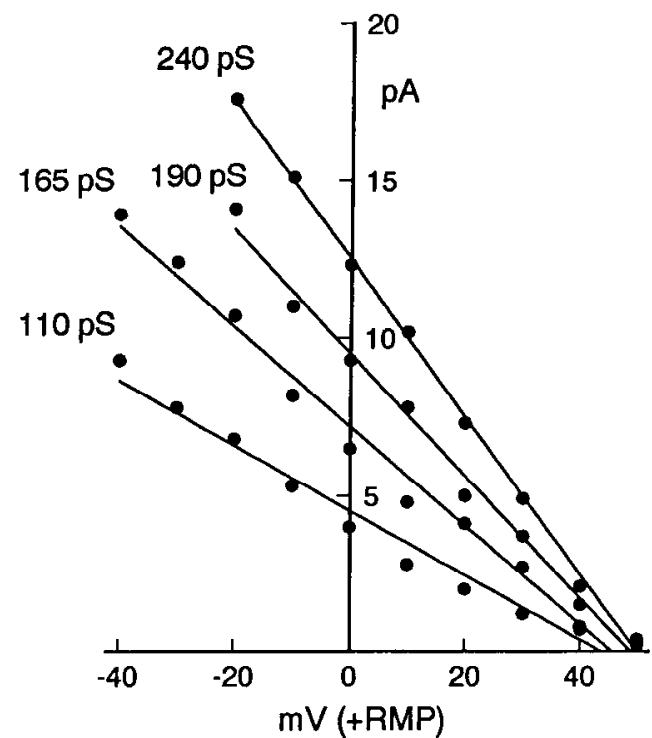

D.

(6)

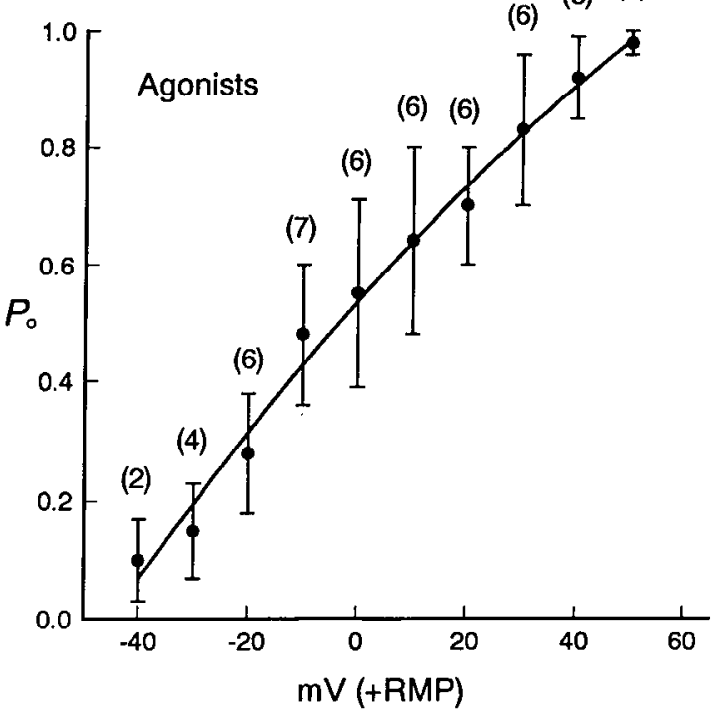

Figure 6. Properties of large-conductance channels. A, Examples of recordings of a large-conductance channel. This channel had a conductance of $240 \mathrm{pS}$. Records at depolarized by $20 \mathrm{mV}$ from resting membrane potential $(R M P$; $10 p)$, at resting potential (center), and at hyperpolarized by $20 \mathrm{mV}$ from resting potential (bottom) are shown. Upward deflections correspond to inward currents. $B$, Current-voltage relationships for largeconductance channels. Values for four different experiments are plotted, and are labeled by their conductances. The lines were fit by linear regression. $C$ and $D$, Fractional channel open probability $\left(\Gamma_{o}\right)$ as a function of membrane potential, for large conductance channels. Data are expressed as mean \pm SD. The number of cells used for measurements at each point is given in parentheses. The curves were fit by second-order polynomial regression; similar fits were obtained with linear regression, and the data were poorly fit by exponentials. $C$, Data for recordings with no drug in the patch pipette solution. $D$, Data for recordings with dopamine or quinpirole $(10 \mu \mathrm{M})$ in the patch pipette solution.

channel. Alternatively, it is possible that only a subset of these cells express the channel, and do so at a high density. Medium spiny neurons can be subdivided into those that project to the globus pallidus and those projecting to the substantia nigra (Reiner and Anderson, 1990). It has heen proposed that dopamine receptor subtypes may be differentially distributed between these two cell populations (Gerfen, 1992), and so a $\mathrm{D}_{2}$-modulated channel might be expected to be restricted to only about half of these cells, but the existence of this receptor segregation is controversial (Surmeier et al., 1992, 1993b).

Although the $85 \mathrm{pS} \mathrm{K} \mathrm{K}^{+}$channel is clearly receptor modulated, it appears to be voltage insensitive in its activation, and so is distinct from those $\mathrm{K}^{+}$channels that participate in action potentials. The molecular diversity of voltage-activated $\mathrm{K}^{+}$channels is well known (Rudy, 1988; Li et al., 1993). Here, we have distinguished among different $\mathrm{K}^{+}$-permeable channels active around resting membrane potential largely on the basis of their single-channel conductances. There appeared to be remarkably many distinct channels, but the $85 \mathrm{pS}$ channel stood out as being active only in the presence of agonists (Fig. 7). We have seen no evidence of any other channels being either activated or inhibited. However, the diversity of channel conductances makes 
Table 8. Occurrence of large-conductance channel openings in the presence and absence of dopaminergic agonists

\begin{tabular}{lcc} 
& & $\begin{array}{l}\text { Patches } \\
\text { with } \\
\text { channel } \\
(\%)\end{array}$ \\
Pipette solution & $\begin{array}{l}\text { Patches } \\
\text { tested }\end{array}$ & $\begin{array}{l}(\%) \\
\text { "Large" cells }\end{array}$ \\
Control & 130 & $5(4 \%)$ \\
Dopamine $(10 \mu \mathrm{M})+$ ascorbic acid $(100 \mu \mathrm{M})$ & 211 & $5(2 \%)$ \\
Quinpirole $(10 \mu \mathrm{M})$ & 141 & $6(4 \%)$ \\
$\quad$ Total agonists & 352 & $11(3 \%)$ \\
"Small" cells & & \\
Control & 43 & $1(2 \%)$ \\
Dopamine $(10 \mu \mathrm{M})+$ ascorbic acid $(100 \mu \mathrm{M})$ & 62 & $2(3 \%)$ \\
Quinpirole $(10 \mu \mathrm{M})$ & 56 & $1(2 \%)$ \\
$\quad$ Total agonists" & 118 & $3(2 \%)$ \\
\hline
\end{tabular}

"The sum of the data for dopamine and for quinpirole. it difficult to state exactly how many channel subtypes were present. Consequently, we can not rule out the possibility that some other channel was also dopamine modulated, while a similar but not identical channel appeared in comparison recordings.

The channels we observed appear to fall into two broad groups. The more frequently encountered group was made up of inwardly rectifying $\mathrm{K}^{+}$-permeable channels. This is consistent with the known properties of neostriatal neurons, which characteristically express a large amount of inward rectification, a $\mathrm{K}^{+}$-mediated conductance active principally at hyperpolarized membrane potentials (Kawaguchi et al., 1989; Uchimura et al., 1989; Calabresi et al., 1990; Galarraga et al., 1994). Studies at the whole-cell level have suggested that striatal inwardly rectifying conductances can be separated into multiple components (Nisenbaum and Wilson, 1993). This would imply that more than one such channel should be present in single-channel recordings, and our results indicate that this is so

The $85 \mathrm{pS} \mathrm{K}{ }^{+}$channel can be thought of as belonging to this group of channels, differing from the related channels in having a much larger conductance. Dopamine, then, could be thought of (at least in part) as increasing the amplitude of an inwardly rectifying $\mathrm{K}^{\prime}$ conductance already present on these cells. At the
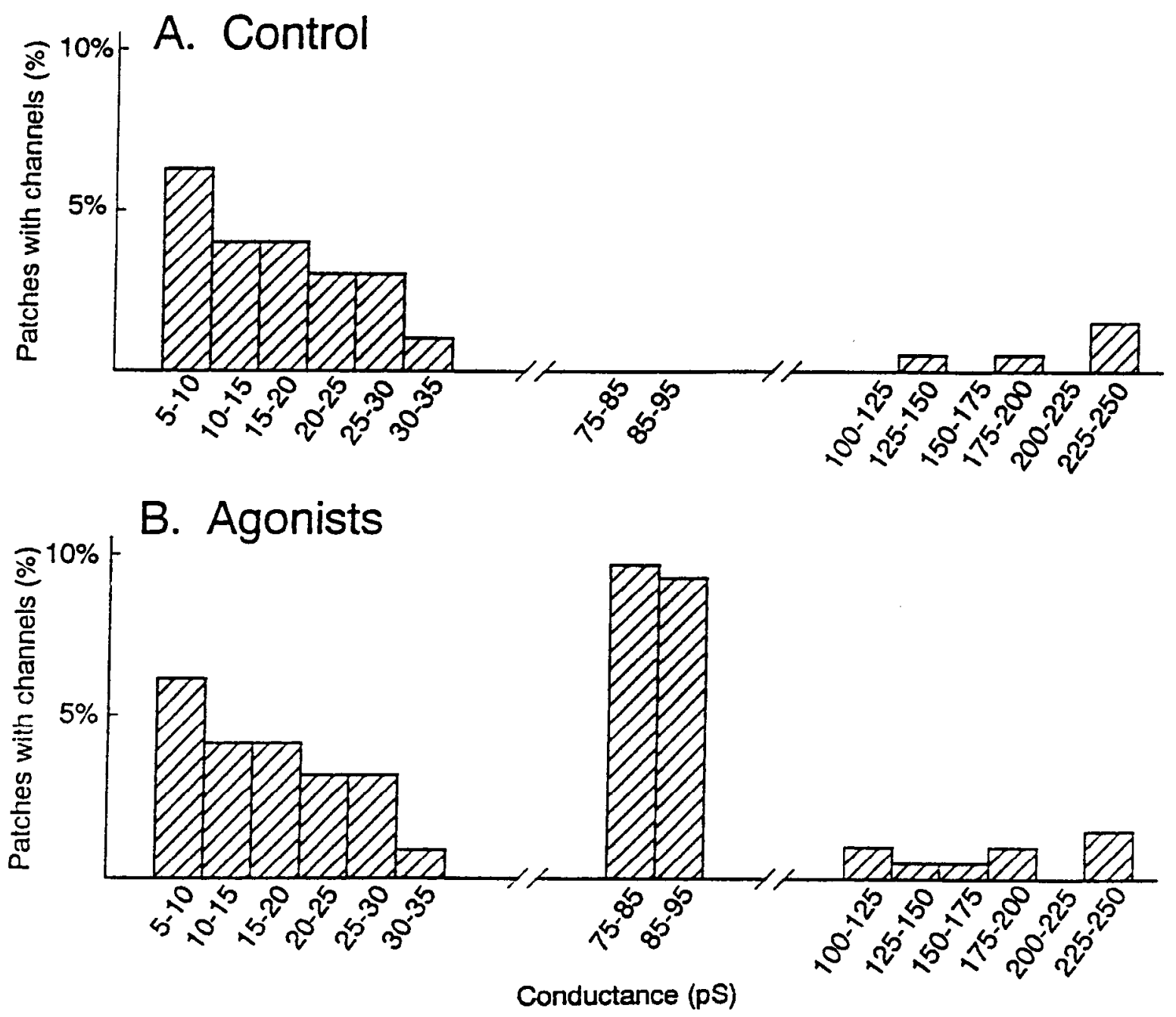

Figure 7. Summary of the percentage of patches containing channels of various conductances, in the absence $(A)$ and the presence $(B)$ of dopaminergic agonists in the cell-attached patch pipette solution. Data from all cell types used in recordings are pooled. The numbers of patches expressing channels of a given conductance range are expressed as the percentage of all patches recorded (173 recordings in $A, 470$ recordings in $B$ ). 
whole-cell lcvel, this would be expected to result in a hyperpolarizing response near resting membrane potential, and thus an inhibition of firing. This is consistent with known $\mathrm{D}_{2}$-mediated effects in substantia nigra neurons (Lacey et al., 1987), but postsynaptic dopamine effects in the caudate-putamen are less well understood. There is evidence for both inhibitory and excitatory dopaminergic responses on neostriatal neurons (Bradshaw et al., 1985; Uchimura et al., 1986; White and Wang, 1986; Ohno et al., 1987). It is important to note that our results do not rule out the existence of other kinds of dopamine-modulated ion channels as well, particularly if these other channels occur on dendrites but not cell bodies, or if they would have been resolved using different voltage protocols or different ionic solutions.

The other channel group we observed was distinguished from both the $85 \mathrm{pS}$ channel and the small-conductance channels by its larger conductances and its voltage sensitivity. The properties of these channels seem very similar to the well-known "maxi$\mathrm{K}$ " group of $\mathrm{Ca}^{2}{ }^{2}$-activated $\mathrm{K}$ ' channels (Blatz and Magleby, 1987; Rudy, 1988). Molecular studies suggest that there are also diverse subtypes of these channels in brain tissue (Reinhart et al., 1989). Because these channels were seen relatively infrequently on these cells, we have not characterized whether they are in fact sensitive to $\mathrm{Ca}^{2+}$. Therefore, our suggestion that they may be $\mathrm{Ca}^{2+}$ activated should be regarded as inferential.

There is further evidence of diversity among those ion channels that are subject to modulation by neurotransmitter receptors. Hippocampal neurons utilize different $\mathrm{K}^{+}$channels for modulation by $\mathrm{GABA}_{\mathrm{B}}$ receptors than by serotonin receptors (Premkumar and Gage, 1994). The $\mathrm{K}^{+}$channel coupled to muscarinic acetylcholine receptors in cardiac tissue shares a number of properties with the $85 \mathrm{pS}$ channel (Birnbaumer et al., 1990). However, the $85 \mathrm{pS}$ channel has approximately double the conductance of the muscarinic channel, and so these appear to be distinct types. There may even be diversity among $D_{2}$ dopamine receptor-coupled $\mathrm{K}^{+}$channels in different tissues. Experiments with blockade by quinine have provided indirect evidence that the $85 \mathrm{pS}$ channel or a very similar channel is activated by $D_{2}$ dopamine autoreceptors in the substantia nigra (Cass and Zahniser, 1990), as well as being present postsynaptically in the striatum (Freedman and Weight, 1989). In contrast, a $\mathrm{K}^{+}$channel activated by $\mathrm{D}_{2}$-like dopamine receptors in the pituitary has been described in single-channel recordings, and clearly differs from the $85 \mathrm{pS}$ channel in conductance, open-closed gating kinetics, and quinine sensitivity (Einhorn et al., 1991). It thus appears likely that $\mathrm{D}_{2}$-like dopamine receptors utilize different $\mathrm{K}^{+}$channels in brain than in pituitary. Apparently there are multiple $\mathrm{K}^{-}$ channels capable of specific modulation by neurotransmitter receptors.

\section{References}

Aghajanian GK, Rasmussen K (1989) Intracellular studies in the facial nucleus illustrating a simple new method for obtaining viable motoneurons in adult rat brain slices. Synapse 3:331-338.

Birnbaumer L, Abramowitz J, Yatani A, Okabe K, Mattera R, Graf R. Santord J, Codina J, Brown AM (1990) Roles of G proteins in coupling of receptors to ionic channels and other effector systems. Crit Rev Biochem Mol Biol 25:225-244.

Blatz AL, Magleby KL (1987) Calcium-activated potassium channels. Trends Neurosci 10:463-467.

Bloch B, I eMoine C (1994) Neostriatal dopamine receptors. Trends Neurosci 17:3-4.

Bradshaw CM, Sheridan RD, Szabadi E (1985) Excitatory neuronal responses to dopamine in the cerebral cortex: involvement of $\mathrm{D}_{2}$ but not $\mathrm{D}_{1}$ dopamine receptors. Br J Pharmacol 86:483-490.

Bunney BS, Walters JR, Roth RH, Aghajanian GK (1973) Dopaminergic neurons: effect of antipsychotic drugs and amphetamine on single cell activity. J Pharmacol Exp Ther 185:560-571.

Bunney BS, Chiodo LA, Grace AA (1991) Midbrain dopamine system electrophysiological functioning: a review and new hypothesis. Synapse 9:79-94.

Calabresi P, Mercuri N, Bernardi G (1990) Synaptic and intrinsic control of membrane excitability of neostriatal neurons. II. An in vitro analysis. J Neurophysiol 63:663-675.

Cass WA, Zahniser NR (1990) Inhibition of striatal dopamine release by the selective D-2 dopamine receptor agonist N-0437 is blocked by quinine. Synapse 5:336-337.

Dawson TM, Bredt DS, Fotuhi M, Hwang PM, Snyder SH (1991) Nitric oxide synthase and neuronal NADPH diaphorase are identical in brain and peripheral tissues. Proc Natl Acad Sci USA 88:7797-7801.

Einhorn LC, Gregerson KA, Oxford GS (1991) $D_{2}$ Dopamine receptor activation of potassium channels in identified rat lactotrophs: wholecell and single-channel recording. J Neurosci 11:3727-3737.

Ferrante RJ, Kowall NW, Beal MF, Richardson EP Jr, Bird ED, Martin JB (1985) Selective sparing of a class of striatal neurons in Huntington's disease. Science 230:561-563.

Freedman JE, Weight FF (1988) Single $\mathrm{K}^{+}$channels activated by $\mathrm{D}_{2}$ dopamine receptors in acutely dissociated neurons from rat corpus striatum. Proc Natl Acad Sci USA 85:3618-3622.

Freedman JE, Weight FF (1989) Quinine potently blocks single $\mathrm{K}^{+}$ channels activated by dopamine $\mathrm{D}-2$ receptors in rat corpus striatum neurons. Eur J Pharmacol 164:341-346.

Galarraga E, Pacheco-Cano MT, Flores-Hernandez JV, Bargas J (1994) Subthreshold rectification in neostriatal spiny projection neurons. Exp Brain Res 100:239-249.

Gerfen CR (1992) The neostriatal mosaic: multiple levels of compartmental organization. Trends Neurosei 15:133-139.

Gerfen CR, Keefe KA (1994) Neostriatal dopamine receptors. Trends Neurosci 17:2-3.

Gingrich JA, Caron MG (1993) Recent advances in the molecular biology of dopamine receptors. Annu Rev Neurosci 16:299-321.

Hahn RA, MacDonald BR (1984) Primate cardiovascular responses mediated by dopamine receptors: effects of $N, N$-di-n-propyldopamine and LY171555. J Pharmacol Exp Ther 229:132-138.

Hamblin MW, Creese I (1983) Behavioral and radioligand binding evidence for irreversible dopamine receptor blockade by $\mathrm{N}$-ethoxycarbonyl-2-ethoxy-1,2-dihydroquinoline. Life Sci 32:2247-2255.

Kawaguchi Y (1993) Physiological, morphological, and histochemical characterization of three classes of interneurons in rat neostriatum. $J$ Neurosci 13:4908-4923.

Kawaguchi Y, Wilson CJ, Emson PC (1989) Intracellular recording of identified neostriatal patch and matrix spiny cells in a slice preparation preserving cortical inputs. J Neurophysiol 62:1052-1068.

Kay AR, Wong RKS (1986) Isolation of neurons suitable for patchclamping from adult mammalian central nervous system. J Neurosci Methods 16:227-238.

Kita H, Kitai ST (1988) Glutamate decarboxylase immunoreactive neurons in rat neostriatum: their morphological types and populations. Brain Res 447:346-352.

Kubota Y, Mikawa S, Kawaguchi Y (1993) Neostriatal GABAergic interneurones contain NOS, calretinin or parvalbumin. Neuroreport $5: 205-208$.

Lacey MG, Mercuri NB, North RA (1987) Dopamine acts on D, receptors to increase potassium conductance in neurones of the rat substantia nigra zona compacta. J Physiol (Lond) 392:397-4I6.

Laduron PM, Leysen JE (1979) Domperidone, a specific in vitro dopamine antagonist, devoid of in vivo central dopaminergic activity. Biochem Pharmacol 28:2161-2165.

Li M, Isacoff E, Jan YN, Jan LY (1993) Assembly of potassium channels. Ann NY Acad Sci 707:51-59.

Lin Y-J, Greif GJ, Freedman JE (1993) Multiple sulfonylurea-sensitive potassium channels: a novel subtype modulated by dopamine. Mol Pharmacol 44:907-910.

Liu J-C, Cox RF, Greif GJ, Freedman JE, Waszczak BL (1994) The putative dopamine $\mathrm{D}_{3}$ receptor agonist 7-OH-DPAT: lack of mesolimbic selectivity. Eur J Pharmacol 264:269-278.

Liu L-X, Kapatos G, Chiodo LA (1992) DA autoreceptor modulation 
of different calcium currents in DA neurons. Soc Neurosci Abstr 18 1516.

Liu L-X, Shen R-Y, Kapatos G, Chiodo LA (1994) Dopamine neuron membrane physiology: characterization of the transient outward current $\left(I_{\mathrm{A}}\right)$ and demonstration of a common signal transduction pathway for $I_{\mathrm{A}}$ and $I_{\mathrm{K}}$. Synapse 17:230-240.

Nathan, C (1992) Nitric oxide as a secretory product of mammalian cells. FASEB J 6:3051-3064.

Nisenbaum ES, Wilson CJ (1993) Striatal spiny neurons possess two types of inwardly-rectifying currents. Soc Neurosci Abstr 19:979.

Ohno Y, Sasa M, Takaori S (1987) Coexistence of inhibitory dopamine D- 1 and excitatory D-2 receptors on the same caudate nucleus neurons. Life Sci 40:1937-1945.

Premkumar LS, Gage PW (1994) Potassium channels activated by GA$\mathrm{BA}_{\mathrm{B}}$ agonists and serotonin in cultured hippocampal neurons. J Neurophysiol 71:2570-2575.

Reiner A, Anderson KD (1990) The patterns of neurotransmitter and neuropeptide co-occurrence among striatal projection neurons: conclusions based on recent findings. Brain Res Rev 15:251-265.

Reinhart PH, Chung S, Levitan IB (1989) A family of calcium depen dent potassium channels from rat brain. Neuron 2:1031-1041.

Rudy B (1988) Diversity and ubiquity of K channels. Neuroscience $25: 729-749$
Seeman P, Van Tol HHM (1994) Dopamine receptor pharmacology Trends Pharmacol Sci 15:264-270.

Stoof JC, Kebabian JW (1984) Two dopamine receptors: biochemistry, physiology and pharmacology. Life Sci 35:2281-2296.

Surmeier DJ, Eberwine J, Wilson CJ, Cao Y, Stefani A, Kitai ST (1992) Dopamine receptor subtypes colocalize in rat striatonigral neurons. Proc Natl Acad Sci USA 89:10178-10182.

Surmeier DJ, Bargas J, Howe A (1993a) Dopamine Dl receptor activation reduces $\mathrm{Ca}^{2+}$ currents in acutely dissociated rat neostriatal neurons. Soc Neurosci Abstr 19:978.

Surmeier DJ, Reiner A, Levine MS, Ariano MA (1993b) Are neostriatal dopamine receptors colocalized? Trends Neurosci 16:299-305.

Uchimura N, Higashi H, Nishi S (1986) Hyperpolarizing and depolarizing actions of dopamine via D-1 and D-2 receptors on nucleus accumbens neurons. Brain Res 375:368-372.

Uchimura N, Cherubini E, North RA (1989) Inward rectification in rat nucleus accumbens neurons. J Neurophysiol 62:1280-1286

Vincent SR, Kimura H (1992) Cytochemical mapping of nitric oxide synthase in the rat brain. Neuroscience 46:755-784.

Weiss B, Zhou L-W, Zhang S-P, Qin Z-H (1993) Antisense oligodeoxynucleotide inhibits $\mathrm{D}_{2}$ dopamine receptor-mediated behavior and $\mathrm{D}_{2}$ messenger RNA. Neuroscience 55:60\%-612.

White FJ, Wang RY (1986) Electrophysiological evidence for the existence of both D-1 and D-2 dopamine receptors in the rat nucleus accumbens. J Neurosei 6:274-280. 